\title{
MITIGATION OF METHANE AND NITROUS OXIDE EMISSIONS FROM FLOOD-IRRIGATED RICE BY NO INCORPORATION OF WINTER CROP RESIDUES INTO THE SOIL ${ }^{(1)}$
}

\author{
Tiago Zschornack ${ }^{(2)}$, Cimélio Bayer ${ }^{(3)}$, Josiléia Acordi Zanatta ${ }^{(4)}$, \\ Frederico Costa Beber Vieira ${ }^{(5)}$ \& Ibanor Anghinoni ${ }^{(3)}$
}

\begin{abstract}
SUMMARY
Winter cover crops are sources of $\mathrm{C}$ and $\mathrm{N}$ in flooded rice production systems, but very little is known about the effect of crop residue management and quality on soil methane $\left(\mathrm{CH}_{4}\right)$ and nitrous oxide $\left(\mathrm{N}_{2} \mathrm{O}\right)$ emissions. This study was conducted in pots in a greenhouse to evaluate the influence of crop residue management (incorporated into the soil or left on the soil surface) and the type of cover-crop residues (ryegrass and serradella) on $\mathrm{CH}_{4}$ and $\mathrm{N}_{2} \mathrm{O}$ emissions from a flooded Albaqualf soil cultivated with rice (Oryza sativa $\mathrm{L}$.). The closed chamber technique was used for air sampling and the $\mathrm{CH}_{4}$ and $\mathrm{N}_{2} \mathrm{O}$ concentrations were analyzed by gas chromatography. Soil solution was sampled at two soil depths (2 and $20 \mathrm{~cm})$, simultaneously to air sampling, and the contents of dissolved organic C (DOC), $\mathrm{NO}_{3}{ }^{-}, \mathrm{NH}_{4}{ }^{+}, \mathrm{Mn}^{2+}$, and $\mathrm{Fe}^{2+}$ were analyzed. Methane and $\mathrm{N}_{2} \mathrm{O}$ emissions from the soil where crop residues had been left on the surface were lower than from soil with incorporated residues. The type of crop residue had no effect on the $\mathrm{CH}_{4}$ emissions, while higher $\mathrm{N}_{2} \mathrm{O}$ emissions were observed from serradella (leguminous) than from ryegrass, but only when the residues were left on the soil surface. The more intense soil reduction verified in the deeper soil layer $(20 \mathrm{~cm})$, as evidenced by higher contents of reduced metal species $\left(\mathrm{Mn}^{2+}\right.$ and $\left.\mathrm{Fe}^{2+}\right)$, and the close relationship between $\mathrm{CH}_{4}$ emission and the DOC contents in the deeper layer indicated that the sub-surface layer was the main $\mathrm{CH}_{4}$ source of the flooded soil with incorporated crop residues. The adoption of management strategies in which crop residues are left on the soil surface is crucial to minimize soil $\mathrm{CH}_{4}$ and $\mathrm{N}_{2} \mathrm{O}$ emissions from irrigated rice fields. In these production systems, $\mathrm{CH}_{4}$ accounts
\end{abstract}

\footnotetext{
(1) Received for publication in april 2010 and approved in december 2010.

(2) Doctorate student of the Post Graduation Program of Soil Science, Federal University of Rio Grande do Sul - UFRGS. Bento Gonçalves Ave., 7712, CEP 91540-000 Porto Alegre (RS). E-mail: tivizs@yahoo.com.br

(3) Professor of the Soil Science Department, UFRGS. CNPq fellowship. E-mails: cimelio.bayer@ufrgs.br; ibanghi@ufrgs.br

(4) Researcher of the Embrapa Western Agropecuary Research Center. BR 163, km 256,3 Dourados (MS), 79804-970. E-mail: josileia@cpao.embrapa.br

(5) Professor of the Federal University of Pampa - UNIPAMPA. Antonio Trilha Ave., 1845, CEP 97300-000 São Gabriel (RS). Email: fredericovieira@unipampa.edu.br
} 
for more than $90 \%$ of the partial global warming potential $\left(\mathrm{CH}_{4}+\mathrm{N}_{2} \mathrm{O}\right)$ and, thus, should be the main focus of research.

Index terms: greenhouse gases, flooded rice, soil management.

\author{
RESUMO: MITIGAÇÃO DAS EMISSÕES DE METANO E DE ÓXIDO \\ NITROSO EM PLANOSSOLO SOB CULTIVO DE ARROZ PELA \\ MANUTENÇÃO DOS RESÍDUOS DE PLANTAS DE COBERTURA \\ EMSUPERFÍCIE
}

\begin{abstract}
Plantas de cobertura de inverno são fontes de Ce de Nem sistemas de produção de arroz irrigado, mas pouco se conhece sobre o efeito do manejo e da qualidade dos seus resíduos culturais nas emissões de metano $\left(\mathrm{CH}_{4}\right)$ e de óxido nitroso $\left(\mathrm{N}_{2} \mathrm{O}\right)$ do solo. O estudo consistiu de um experimento conduzido em casa de vegetação e teve como objetivo principal avaliar a influência do manejo (incorporado ou em superfície) e do tipo de resíduos culturais (azevém e serradela) de plantas de cobertura sobre as emissões de $\mathrm{CH}_{4}$ e de $\mathrm{N}_{2} \mathrm{O}$ de um Planossolo Háplico sob cultivo de arroz irrigado por inundação. Utilizou-se o método da câmara fechada, e as concentrações de $\mathrm{CH}_{4}$ e de $\mathrm{N}_{2} \mathrm{O}$ nas amostras de ar foram determinadas por cromatografia gasosa. Coletas da solução do solo em duas profundidades $(2$ e $20 \mathrm{~cm}$ ) foram realizadas simultaneamente às coletas de ar. A manutenção dos resíduos culturais na superfície do solo resultou em menor emissão de $\mathrm{CH}_{4}$ e de $\mathrm{N}_{2} \mathrm{O}$ em comparação à sua incorporação. O tipo de residuo cultural não teve efeito na emissão de $\mathrm{CH}_{4}$, enquanto para o $\mathrm{N}_{2} \mathrm{O}$ a distinção entre os residuos ocorreu apenas quando estes foram mantidos na superfície do solo-condição na qual as maiores emissões ocorreram com a adição dos resíduos da leguminosa (serradela). $O$ processo mais intenso de redução do solo em subsuperfície $(20 \mathrm{~cm})$, evidenciado pelos maiores teores de ions reduzidos $\left(\mathrm{Mn}^{2+}\right.$ e $\left.\mathrm{Fe}^{2+}\right)$, e a estreita relação entre a emissão de $\mathrm{CH}_{4}$ e os teores de Corgânico dissolvido nessa profundidade indicam que a camada subsuperficial foi a principal fonte de $\mathrm{CH}_{4}$ quando da incorporação dos residuos culturais. A adoção de estratégias de manejo que promovam a manutenção dos resíduos culturais na superfície do solo é fundamental quando se visa à mitigação das emissões de $\mathrm{CH}_{4}$ e $\mathrm{N}_{2} \mathrm{O}$ em solos sob cultivo de arroz irrigado. $\mathrm{O} \mathrm{CH}_{4}$ compõe mais de $90 \%$ do potencial de aquecimento global parcial $\left(\mathrm{CH}_{4}+\mathrm{N}_{2} \mathrm{O}\right)$ nesses sistemas de produção e, portanto, deve ser o foco principal da pesquisa.
\end{abstract}

Termos de indexação: gases de efeito estufa, arroz irrigado, manejo de solo.

\section{INTRODUCTION}

The mitigation of greenhouse gases (GHG) emissions from agricultural soil, which is estimated at about $20 \%$ in the word and $80 \%$ in Brazil (Cerri et al., 2009), is fundamental to decrease the contribution of agriculture and land use changes to global warming, which is estimated at about $20 \%$ in the world and $80 \%$ in Brazil (Cerri et al., 2009). Particularly, methane $\left(\mathrm{CH}_{4}\right)$ is a major issue in flooded rice (Oryza sativa L.) fields, where this source accounts for 10 $40 \%$ of the global $\mathrm{CH}_{4}$ emissions (Le Mer \& Roger, 2001; Dalal et al., 2008). In Brazil, the contribution from paddy rice fields to $\mathrm{CH}_{4}$ emissions is lower, with about $3 \%$ of the total $\mathrm{CH}_{4}$ emission only (MCT, 2006). However, in the South, the region of the majority of paddy rice fields in Brazil, flooded rice fields contribute to $12 \%$ of the total $\mathrm{CH}_{4}$ emissions and this relative contribution increases to $18 \%$ in Rio Grande do Sul State, the largest rice producer in Brazil, where summer rice is grown on more than 1.1 million hectare (CONAB, 2010).
In flood-irrigated rice fields, anaerobic soil conditions lead to $\mathrm{CH}_{4}$ generation as the final product of organic compost decomposition by methanogenic bacteria (Dalal et al., 2008). Several factors inherent to soil (Wang et al., 1999, Setyanto et al., 2002) and climate (Schütz et al., 1990; Yang \& Chang, 1998) affect $\mathrm{CH}_{4}$ emissions to the atmosphere. Understanding the effects and interactions of soil and irrigation management practices under different conditions is crucial for developing effective strategies of $\mathrm{CH}_{4}$ emission minimization (Stepniewski \& Stepniewska, 2009).

At the international level, the effect of irrigation management on $\mathrm{CH}_{4}$ emissions has been emphasized, since single or multiple drainages during a rice growing season can reduce net emissions by $17-64 \%$, in comparison to continuously flooded systems (Minamikawa \& Sakai, 2005). In the South of Brazil however, the drainage of flooded rice fields should be absolutely avoided, in view of the environmental risk of water contamination with nutrients (Marchezan et al., 2007) and pesticides (Marchesan et al., 2007; 
Silva et al., 2009), significant increases in the volume of irrigation water and higher energy costs due for reflooding (Macedo et al., 2007). This management practice would jeopardize the environmental and economic sustainability. In addition, rice field drainage can on the one hand decrease $\mathrm{CH}_{4}$ but on the other increase nitrous oxide $\left(\mathrm{N}_{2} \mathrm{O}\right)$ emissions (Xiong et al., 2007; Johnson-Beebout et al., 2009), diminishing the benefits of drainage for the net global warming potential.

The residue quality and management of the crop preceding rice also deserve attention, as these residues constitute an important source of labile C, which stimulates soil microbial activity and usually intensifies soil $\mathrm{CH}_{4}$ emissions (Cochran et al., 1997). In Rio Grande do Sul State, ryegrass (Lolium multiflorum Lam.) is a grass plant cultivated in large lowland areas during the winter, serving as pasture in this period. The cultivation of winter legume species for forage, such as birdsfoot trefoil (Lotus corniculatus), clover (Trifolium spp.) and native serradella [Ornithopus micranthus (Benth.) Arechavaleta] is still modest, but has been promoted as protein source in integrated rice-pasture systems (Scivittaro et al.; 2002; Reis \& Saibro, 2004). Therefore, for the development of regional rice production systems with low $\mathrm{CH}_{4}$ emission, the assessment of the quality and management effect of winter crop residues on the fluxes of this gas is essential.

The quality and management of winter crop residues can also affect soil $\mathrm{N}_{2} \mathrm{O}$ emissions by modifying soil $\mathrm{NH}_{4}{ }^{+}$and $\mathrm{NO}_{3}{ }^{-}$contents, which in turn are substrate for nitrification and denitrification, respectively. These are the main processes related to the $\mathrm{N}_{2} \mathrm{O}$ generation in soil (Khalil et al., 2004). Consequently, legume species could exacerbate $\mathrm{N}_{2} \mathrm{O}$ emissions from flooded rice production systems (Aulakh et al., 2001; Kaewpradit et al., 2008), but there is little evidence regarding the effect of different residue management systems on the emission of these greenhouse gases (Shan et al., 2008; Kaewpradit et al., 2008).

This greenhouse study aimed to evaluate (i) the influence of crop residues (legume and grass species) and their management (incorporated into the soil or left on the soil surface) on $\mathrm{CH}_{4}$ and $\mathrm{N}_{2} \mathrm{O}$ emissions from an Albaqualf soil under flooded rice, (ii) their influence on soil reduction and interaction with the soil $\mathrm{CH}_{4}$ and $\mathrm{N}_{2} \mathrm{O}$ emission, and (iii) the contribution of these gases to the partial global warming potential, in equivalent $\mathrm{CO}_{2}$, taking their respective warming potentials into account.

\section{MATERIAL AND METHODS}

\section{Experiment}

The study was carried out in a greenhouse of the Soil Science Department of the Federal University of Rio Grande do Sul (UFRGS), Porto Alegre, RS, Brazil, from October 2007 to January 2008. The treatments consisted of two crop residue managements (incorporated into the soil or left on the surface) using residues of ryegrass (grass) and of serradella (legume), both winter cover crop species. The treatments were arranged in a completely randomized design, with three replications.

The soil was classified as Albaqualf (US Soil Taxonomy) or Planossolo Háplico eutrófico arênico, according to Brazilian Soil Classification System (Embrapa, 2006). Soil was collected from the Experimental Field of Rice Research of the Instituto Rio Grandense do Arroz (EEA/IRGA), close to Cachoeirinha, State of RS, in the 0-20 cm layer. Soil analysis determined the following chemical and physical properties: $210 \mathrm{~g} \mathrm{~kg}^{-1}$ clay; $31 \mathrm{~g} \mathrm{~kg}^{-1}$ organic matter; $18 \mathrm{mg} \mathrm{dm}^{-3} \mathrm{P}$ (Mehlich-1); $38 \mathrm{mg} \mathrm{dm}^{-3} \mathrm{~K}$ (Mehlich-1); 0.9 and $0.3 \mathrm{cmol}_{\mathrm{c}} \mathrm{dm}^{-3}$ exchangeable $\mathrm{Ca}$ and $\mathrm{Mg}\left(\mathrm{KCl} 1.0 \mathrm{~mol} \mathrm{~L}^{-1}\right)$, respectively; $\mathrm{CEC}_{\mathrm{pH} 7}=$ $11 \mathrm{cmol}_{\mathrm{c}} \mathrm{dm}^{-3}$ and $\mathrm{pH}_{\text {water }}=4.4$. The soil was previously sieved $(10 \mathrm{~mm})$ and filled into PVC pots (22 L), forming a $20 \mathrm{~cm}$ layer (about $12 \mathrm{~kg}$ ). Crop residues were dried $\left(60{ }^{\circ} \mathrm{C}\right)$, chopped $(50 \mathrm{~mm})$ and applied to the soil in each pot at quantities equivalent to $7.5 \mathrm{Mg} \mathrm{ha}^{-1}$. After crop residue addition, the soil moisture was maintained near field capacity for 25 days.

Rice seedlings (cv IRGA 417) were transplanted to the pots after emergence and primary root emission, at about $30{ }^{\circ} \mathrm{C}$ in water. Ten seedlings were initially planted in each pot, in a circle. At the stage of the third leaf emission, uniform seedlings were selected and only five plants were maintained in each pot. Then the soil was flooded with a water layer of $10 \mathrm{~cm}$ that was maintained until the end of the study. Soil fertilization consisted of the application of 960 and $1,440 \mathrm{mg} /$ pot of $\mathrm{K}_{2} \mathrm{O}$ and $\mathrm{P}_{2} \mathrm{O}_{5}$, respectively, with potassium chloride and triple superphosphate before transplanting. At planting, $240 \mathrm{mg} \mathrm{N}$ and $180 \mathrm{mg}$ sulfur were applied per plot, using urea and ammonium sulphate. When the rice plants had three to four leaves, $1,200 \mathrm{mg} \mathrm{N}$ and $720 \mathrm{mg} \mathrm{K}_{2} \mathrm{O}$ were applied per plot, as urea and potassium chloride, respectively. The fertilizer quantities in this study were calculated for an optimum rice development, estimated based on a previous study using the same soil (Fraga et al., 2010).

\section{Air sampling and gas analysis}

PVC cylinders (height $45 \mathrm{~cm}$, diameter $25 \mathrm{~cm}$ ) were used as pots, by closing the bottom with a PVC cap, while a drain channel (depth $20 \mathrm{~mm}$ ) was fixed at the top. On this channel, a closed chamber was placed for each air sampling. The system was hermetically closed by water in the channel (Gomes et al., 2009) (Figure 1).

The PVC chambers, with the same diameter as the pots and a height of $60 \mathrm{~cm}$, were equipped with three-way valves coupled to the syringes for air 


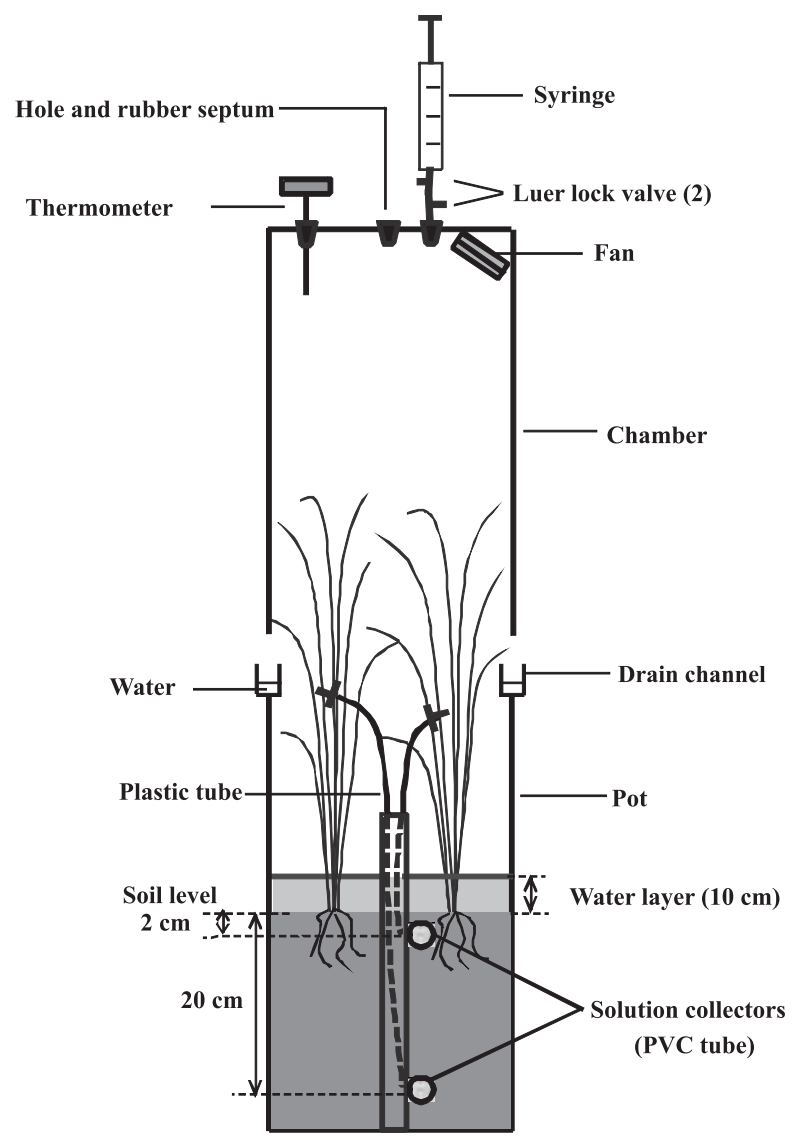

Figure 1. Closed chamber for air sampling and soil solution collectors.

sampling, with digital thermometers to monitor the inner chamber temperature, and a hole (diameter $10 \mathrm{~mm}$ ) to equilibrate the internal pressure of the system when closed by a rubber septum for air sampling. On the inside, a $12 \mathrm{~V}$ fan was installed, which was turned on $30 \mathrm{~s}$ before each air sampling to homogenize the inner atmosphere of the chambers.

The $\mathrm{CH}_{4}$ and $\mathrm{N}_{2} \mathrm{O}$ emissions were analyzed in two sampling events before soil flooding (8 and 1 days before flooding) and in seven sampling events after that $(1,6,13,20,28,58$, and 86 days after floodingDAF). Air was sampled within the chambers by polypropylene syringes $(20 \mathrm{~mL})$ with valves at 5,10 , 15 and 20 min after closing the chamber. Further details related to the sampling procedure were described by Gomes et al. (2009).

The syringes containing the air samples were stored in a cooling box, maintained at low temperature and taken to the Environmental Biogeochemical Laboratory of UFRGS, where they were analyzed by gas chromatography within no more than $24 \mathrm{~h}$ after sampling. The chromatograph (Shimadzu GC 2014 "Greenhouse") was equipped with three packed columns at $70{ }^{\circ} \mathrm{C}, \mathrm{N}_{2}$ as carrier gas at a flow of $26 \mathrm{~mL} \mathrm{~min}^{-1}$, an injector with $1 \mathrm{~mL}$ sample loop for direct injection at $250{ }^{\circ} \mathrm{C}$, an electron capture detector (ECD) at $325^{\circ} \mathrm{C}$ for $\mathrm{N}_{2} \mathrm{O}$ detection and flame ionization detector (FID) at $250{ }^{\circ} \mathrm{C}$ for $\mathrm{CH}_{4}$.

The $\mathrm{N}_{2} \mathrm{O}$ and $\mathrm{CH}_{4}$ fluxes were calculated based on the following equation:

$$
f=\frac{\Delta Q}{\Delta t} \frac{P V}{R T} \frac{1}{A}
$$

where $f$ is the nitrous oxide or methane flux $\left(\mu \mathrm{g} \mathrm{m}^{-2}\right.$ $\mathrm{h}^{-1} \mathrm{~N}_{2} \mathrm{O}$ or $\mathrm{CH}_{4}$ ), Q is the gas quantity $\left(\mu \mathrm{g} \mathrm{N}_{2} \mathrm{O}\right.$ or $\mathrm{CH}_{4}$ ) in the chamber at sampling, $\mathrm{P}$ is the atmospheric pressure (atm) in the inner chamber - assumed as $1 \mathrm{~atm}, \mathrm{~V}$ is the chamber volume $(\mathrm{L}), \mathrm{R}$ is the constant for ideal gases $\left(0.08205 \mathrm{~atm} \mathrm{~L} \mathrm{~mol}{ }^{-1} \mathrm{~K}^{-1}\right)$, $\mathrm{T}$ is the temperature within the chamber at sampling (K) and $\mathrm{A}$ is the basal area of the chamber $\left(\mathrm{m}^{2}\right)$. Increase rates of the gas concentration within the chamber were estimated by the angular coefficient of the linear regression adjusted by the ratio between time and gas concentrations. From the rates of $\mathrm{CH}_{4}$ and $\mathrm{N}_{2} \mathrm{O}$ fluxes, daily emissions were estimated and emission for the total period (90 days) was calculated by integrating the daily emissions (Gomes et al., 2009). Based on the accumulated $\mathrm{CH}_{4}$ and $\mathrm{N}_{2} \mathrm{O}$ emissions and taking into account the global warming potential of each gas in comparison to carbon dioxide $-\mathrm{CO}_{2}(25$ times for $\mathrm{CH}_{4}$ and 298 times for $\mathrm{N}_{2} \mathrm{O}$; Forster et al., 2007), the emissions were calculated in equivalent $\mathrm{CO}_{2}$ and the sum was called "partial Global Warming Potential” (partialGWP).

\section{Soil solution sampling and analysis}

The soil solution was sampled simultaneously to the air. Individual collectors were placed in each pot at a soil depth of 2 and $20 \mathrm{~cm}$ (Figure 1). Collectors consisted of PVC cylinders (diameter $25 \mathrm{~mm}$, length $50 \mathrm{~mm}$ ), both ends covered by a nylon mesh of $0.1 \mathrm{~mm}$ pore size. The two collectors of each pot were horizontally fixed to another PVC tube (diameter $25 \mathrm{~mm}$, length $40 \mathrm{~mm}$ ), in order to maintain them at the desired depth of 2 and $20 \mathrm{~cm}$. In the center of the cylinder, a plastic tube was connected to the collectors at each depth and extended to about $30 \mathrm{~cm}$ above the soil surface. The upper end was closed by a valve to prevent oxygen diffusion.

The soil solution was sampled 1, 6, 13, 20, and 28 DAF, by suction using syringes $(60 \mathrm{~mL})$ equipped with three-way valves, coupled to the upper end of the plastic tubes. Solution samples were immediately filtered through regenerated cellulose (pore diameter $0.45 \mu \mathrm{m}$ ) to determine dissolved organic C (DOC) in a Shimadzu - TOC VCSH analyzer. Twenty mL of each solution sample was frozen at about $-5^{\circ} \mathrm{C}$ for subsequent analysis of $\mathrm{NH}_{4}{ }^{+}$and $\mathrm{NO}_{3}{ }^{-}$concentration by distillation, while $10 \mathrm{~mL}$ were stored in a refrigerator at $1-2{ }^{\circ} \mathrm{C}$ after adding $1 \mathrm{~mL} \mathrm{HCl} 2 \mathrm{~mol} \mathrm{~L}^{-1}$ 
for $\mathrm{Fe}^{2+}$ and $\mathrm{Mn}^{2+}$ determination by atomic absorption spectrometry (Tedesco et al., 1995).

\section{Statistical analysis}

The $\mathrm{CH}_{4}$ and $\mathrm{N}_{2} \mathrm{O}$ total emissions were submitted to ANOVA and differences among means were evaluated by the Tukey test at $5 \%$. Relationship among soil solution variables and $\mathrm{CH}_{4}$ and $\mathrm{N}_{2} \mathrm{O}$ fluxes were evaluated by the statistical significance of linear and exponential coefficients, using SigmaPlot for Windows 11.0 (Systat Software, Inc.). When both models were significant, the one with the higher $\mathrm{R}^{2}$ was chosen.

\section{RESULTS AND DISCUSSION}

\section{Soil $\mathrm{CH}_{4}$ emission}

The variations in $\mathrm{CH}_{4}$ soil emissions, after flooding, were similar in time but different in magnitude, according to the crop residue management (Figure $2 a$ ). The incorporation of ryegrass and serradella into the soil induced greater $\mathrm{CH}_{4}$ emissions than residues left on the soil surface. However, there was no effect of the crop residue type (grass or legume) on $\mathrm{CH}_{4}$ soil emissions (Figure 2a). Crop residue applications increased $\mathrm{CH}_{4}$ production and emissions from the soil after flooding because the anaerobic decomposition of residues does not only provide substrate for methanogenesis, as labile organic $\mathrm{C}$ compounds, but also induces a reduction of the soil redox potential (Dalal et al., 2008).

The management of crop residues affected the beginning of emissions as well as the emission rates (Figure 2a). In soils with incorporated crop residues, $\mathrm{CH}_{4}$ emissions were very low up to $6 \mathrm{DAF}$, increasing markedly thereafter and peaking in $353 \mathrm{mg} \mathrm{m}^{-2} \mathrm{~h}^{-1}$ $\mathrm{CH}_{4}, 28 \mathrm{DAF}$. In the soil with residue maintenance on the surface, in turn, $\mathrm{CH}_{4}$ emissions were low up to $20 \mathrm{DAF}$ and only thereafter the emission rates increased, although the values were consistently lower than from soils with incorporated residues. The maximum emission rate from the non-incorporated residue treatment was measured $58 \mathrm{DAF}$ and its magnitude was about four times lower $\left(98 \mathrm{mg} \mathrm{m}^{-2} \mathrm{~h}^{-1}\right.$ $\mathrm{CH}_{4}$ ) than the highest rate in the residue-incorporated treatment (Figure 2a). The maintenance of crop residues on the surface diminishes the contact between residues and soil in comparison to incorporated residues, which presumably delays and decreases the intensity of anaerobic decomposition and soil reduction, reducing the $\mathrm{CH}_{4}$ production/emission (Harada et al., 2007).

As a consequence of the anticipated emission and higher emission rates, greater accumulated emissions were observed from soils with incorporated crop residues than from soil with residues left on the surface (mean of 356 and $111 \mathrm{~g} \mathrm{~m}^{-2} \mathrm{CH}_{4}$, respectively; Figure 2b). However, the type of crop residue had no effect on total $\mathrm{CH}_{4}$ emission for the period, as the mean values (incorporated and on surface) were 236 and $230 \mathrm{~g} \mathrm{~m}^{-2} \mathrm{CH}_{4}$ for ryegrass and serradella, respectively (Figure 2b). The greater $\mathrm{CH}_{4}$ emissions after crop residue incorporation in comparison to their maintenance on the surface contribute to the understanding of why $\mathrm{CH}_{4}$ emissions from flooded notillage rice fields are lower than from conventional systems, as verified for a Gleysol in the South of Brazil (Costa, 2005). The results of this study clarify that crop residue incorporation by plowing and disking, typical for conventional tillage systems in the region, leads to an increase in soil $\mathrm{CH}_{4}$ emissions, since labile $\mathrm{C}$ is added to subsurface soil layers, increasing the potential for soil reduction (lower Eh values) and, in
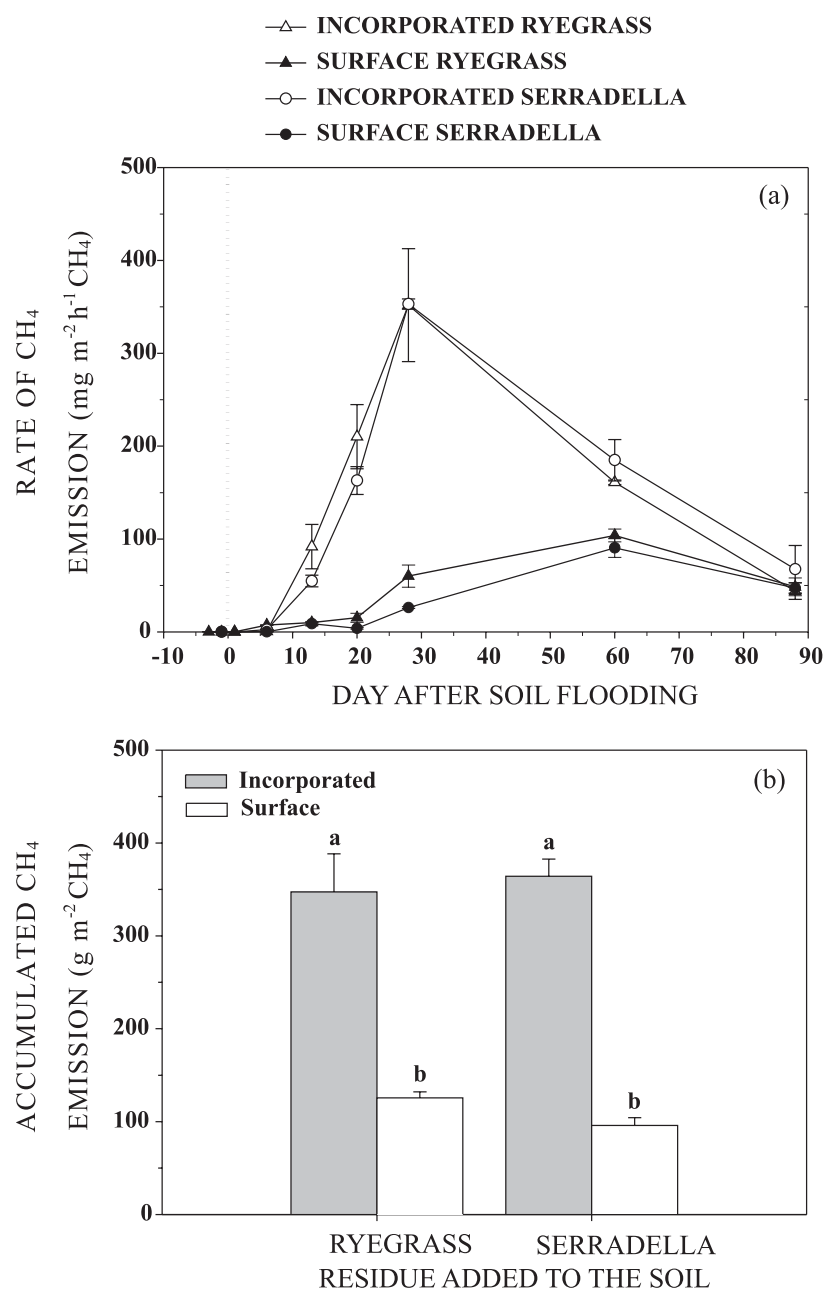

Figure 2. Emission rates (a) and accumulated emission (b) of $\mathrm{CH}_{4}$ from a flooded Albaqualf cultivated with rice as affected by management (incorporation or maintenance on soil on the soil surface) of ryegrass and serradella residues. Vertical bars indicate standard deviation. Different letters on bars indicate statistical difference by Tukey's test at $5 \%$. 
this condition, contribute effectively to $\mathrm{CH}_{4}$ production. On the other hand, crop residues left on the soil surface in no tillage keep this C source in the top soil layer, where methanogenesis is limited by the presence of oxygen dissolved in the water (Conrad, 2002; Dalal et al., 2008).

The effect of crop residue management on the moment of beginning of $\mathrm{CH}_{4}$ emissions was related to the different intensity of the soil reduction process when residues had been incorporated or left on the surface, which was evaluated in this study based on $\mathrm{NO}_{3}{ }^{-}$disappearance (reduction) and the increment of reduced species of $\mathrm{Mn}^{2+}$ and $\mathrm{Fe}^{2+}$ in the soil solution. Based on the changes in these ions, the reduction process was less intense in the surface layer $(2 \mathrm{~cm})$ than at $20 \mathrm{~cm}$ depth (Figure 3). At $20 \mathrm{~cm}$, the reduction was intensified by crop residue incorporation into the soil, as labile $\mathrm{C}$ stimulated the anaerobic microorganisms to sequentially reduce $\mathrm{NO}_{3}{ }^{-}$to $\mathrm{N}_{2} /$ $\mathrm{N}_{2} \mathrm{O}, \mathrm{Mn}^{4+}$ to $\mathrm{Mn}^{2+}$, and $\mathrm{Fe}^{3+}$ to $\mathrm{Fe}^{2+}$ (Figure 3d,e,f). The fast decrease of $\mathrm{NO}_{3}{ }^{-}$concentration indicates its use as the first alternative electron acceptor, followed by $\mathrm{Mn}^{4+}$, but the high $\mathrm{Mn}^{2+}$ concentrations observed one (1) DAF evidence that this element was reduced concomitantly to $\mathrm{NO}_{3}{ }^{-}$. According to Huang et al. (2009), the $\mathrm{NO}_{3}{ }^{-}$contents in soil decrease markedly within less than $48 \mathrm{~h}$ after flooding, while the reduction of the other ions occurs subsequently to nitrate reduction.
The $\mathrm{Fe}^{3+}$ reduction is fundamental for $\mathrm{CH}_{4}$ production (Ali et al., 2009; Huang et al. 2009) and, according to some studies, the methanogenesis process is only activated after the reduction of about $90 \%$ of $\mathrm{Fe}^{3+}$ to $\mathrm{Fe}^{2+}$ (Setyanto et al., 2002) and organic compounds begin to be used as electron acceptors by anaerobic bacteria (Conrad, 2002). In this way, the $\mathrm{CH}_{4}$ emission increased from $13 \mathrm{DAF}$ onwards in the soil with incorporated residues, coinciding with an intense $\mathrm{Fe}^{3+}$ reduction to $\mathrm{Fe}^{2+}$ at $20 \mathrm{~cm}$ depth. At this time, more than 90 and $70 \%$ of $\mathrm{Fe}^{3+}$ at $20 \mathrm{~cm}$ depth had already been reduced to $\mathrm{Fe}^{2+}$ in the treatments with incorporated ryegrass and serradella residues, respectively. On the other hand, the $\mathrm{CH}_{4}$ emission from soil with residues on the surface began only $28 \mathrm{DAF}$, which is also coherent with the $\mathrm{Fe}^{3+}$ reduction to $\mathrm{Fe}^{2+}, 20$ DAF (Figure $3 \mathrm{f}$ ). Despite the coherence between $\mathrm{CH}_{4}$ emissions and $\mathrm{Fe}^{3+}$ reduction, the results of this study suggest that $\mathrm{CH}_{4}$ production set in before the complete reduction of $\mathrm{Fe}^{3+}$ to $\mathrm{Fe}^{2+}$, which can be explained by the possible occurrence of anaerobic activity and $\mathrm{CH}_{4}$ production at soil microsites, where the reduction process was faster than in the soil matrix (Conrad, 2002).

In general, the application and maintenance of crop residues on the soil surface resulted in greater DOC contents at $2 \mathrm{~cm}$ depth (Figure $4 \mathrm{a}$ ), although the changes in their contents were not related to the $\mathrm{CH}_{4}$ emission from the soil (Figure 4b). The incorporation of residues into the soil, in turn, led to increases in
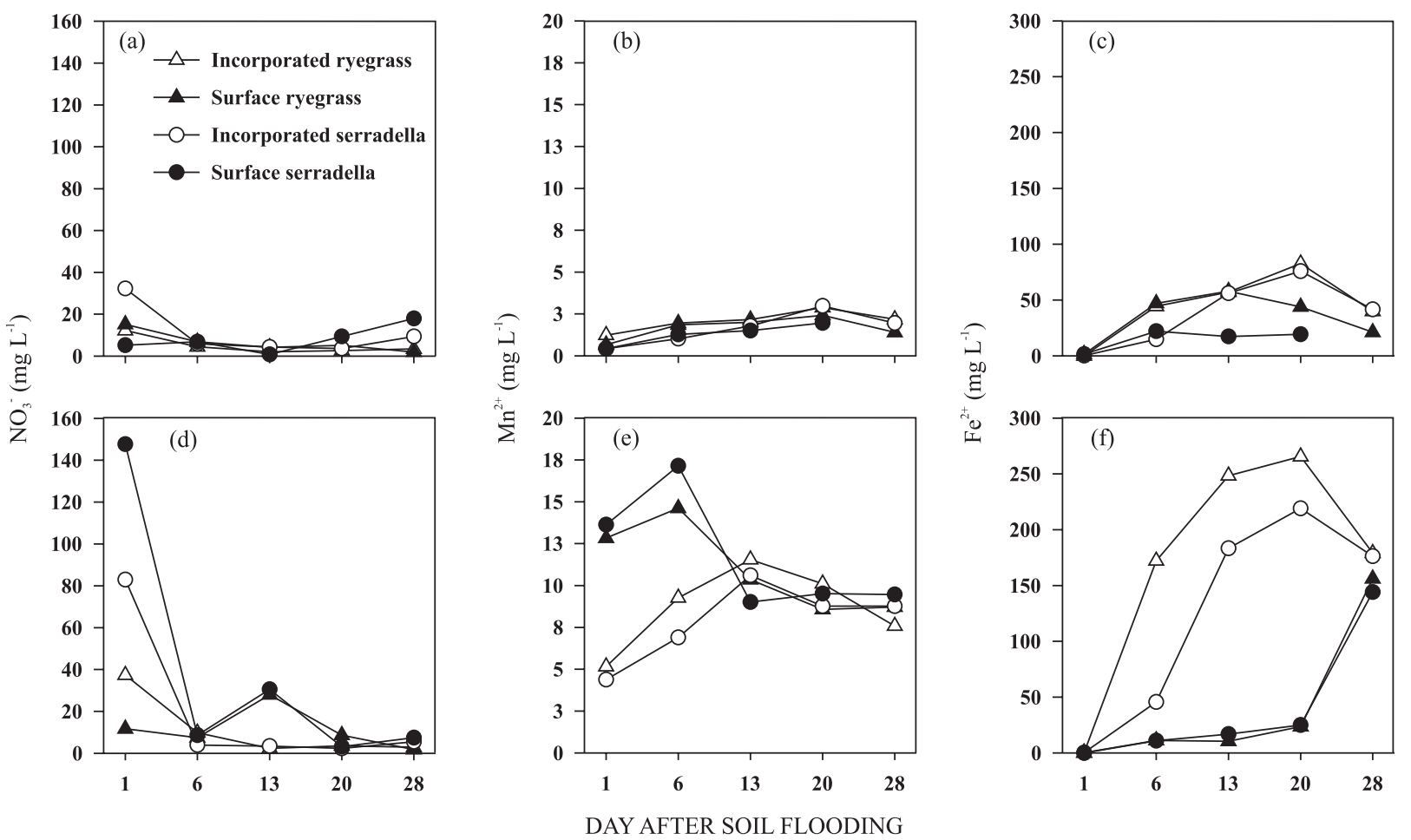

Figure 3. Concentration of nitrate $\left(\mathrm{NO}_{3}^{-}\right)$, manganese $\left(\mathrm{Mn}^{2+}\right)$ and iron $\left(\mathrm{Fe}^{2+}\right)$ in the solution of a flooded Albaqualf at depth of $2(a, b, c)$ and $20 \mathrm{~cm}(d, e, f)$ affected by the residue management (incorporated or left on the soil surface) of ryegrass and serradella. 
DOC contents at $20 \mathrm{~cm}$ depth (Figure $4 \mathrm{c}$ ), in an exponential relationship with soil $\mathrm{CH}_{4}$ emissions $\left(\mathrm{R}^{2}=0.90 ; \mathrm{p}<0.0001\right)$ (Figure $\left.4 \mathrm{~d}\right)$. DOC is one of the major sources of labile $\mathrm{C}$ in flooded soils and is therefore strongly related with the $\mathrm{CH}_{4}$ production (Lu et al., 2000).

The main $\mathrm{CH}_{4}$ source, according to the results, was the subsurface soil layer, where the reduction process was more intense, as evidenced by the contents of $\mathrm{NO}_{3}^{-}, \mathrm{Mn}^{2+}$ and $\mathrm{Fe}^{2+}$ in soil solution. This soil reduction condition is crucial for methanogenesis, which only occurs at Eh values below -150 mV (Minamikawa \& Sakai, 2006; Stepniewski \& Stepniewska, 2009). On the other hand, the occurrence of oxygen dissolved in the water of the surface soil layer due to the diffusion of $\mathrm{O}_{2}$ by the aerenchyma of rice plants (Stepniewski \& Stepniewska, 2009) possibly restricted methanogenesis in the surface soil layer, despite the availability of substrate (DOC) for this process.

Regarding the type of crop residue, a larger $\mathrm{CH}_{4}$ emission rate could be expected from soils under legume crops than under grass, due to the faster decomposition rate mainly attributed to the lower $\mathrm{C} /$ $\mathrm{N}$ ratio and, therefore, greater labile $\mathrm{C}$ production for methanogenesis (Kaewpradit et al., 2008). A plausible explanation for the absence of difference between crop residue types in terms of $\mathrm{CH}_{4}$ soil emissions is the interval of 25 days between the time of crop residue application and transplanting of rice seedlings to the pots. The residue decomposition in this period, before the experiment, probably induced the great similarity of emissions between the two crop residues after flooding. However, it is noteworthy that the applied procedure is similar to the usually applied in rice fields, where the crop residue management (tillage in conventional systems or herbicide application in notill) is performed in non-flooded soil conditions, then the rice is sown and flooded about 20 days after plant emergence (Macedo et al., 2007).

The increase in $\mathrm{CH}_{4}$ emissions was exponential with increasing air temperature in the treatments with residue incorporation and applied to the surface (Figure 5), which can be due to both the increase in the soil methanogenic activity (van Hulzen et al., 1999) and the increase in the gas transport through the aerenchyma in the rice plants (Hosono \& Nouchi, 1997). From the exponential equation coefficients, adjusted to air temperature and $\mathrm{CH}_{4}$ emission rates, the value of the $Q_{10}$ factor was estimated at 10 and 35 , respectively, for the treatments with crop residues incorporated into the soil or left on the surface. These values represent a 10 and 35 fold increase in $\mathrm{CH}_{4}$ emissions with an $10{ }^{\circ} \mathrm{C}$ increase in the air temperature. The $\mathrm{Q}_{10}$ values estimated in this study are coherent with the range of 1.5 to 28 reported in literature for $\mathrm{Q}_{10}$ values for $\mathrm{CH}_{4}$ production in flooded soils (Segers, 1998; Rath et al., 2002). On the other
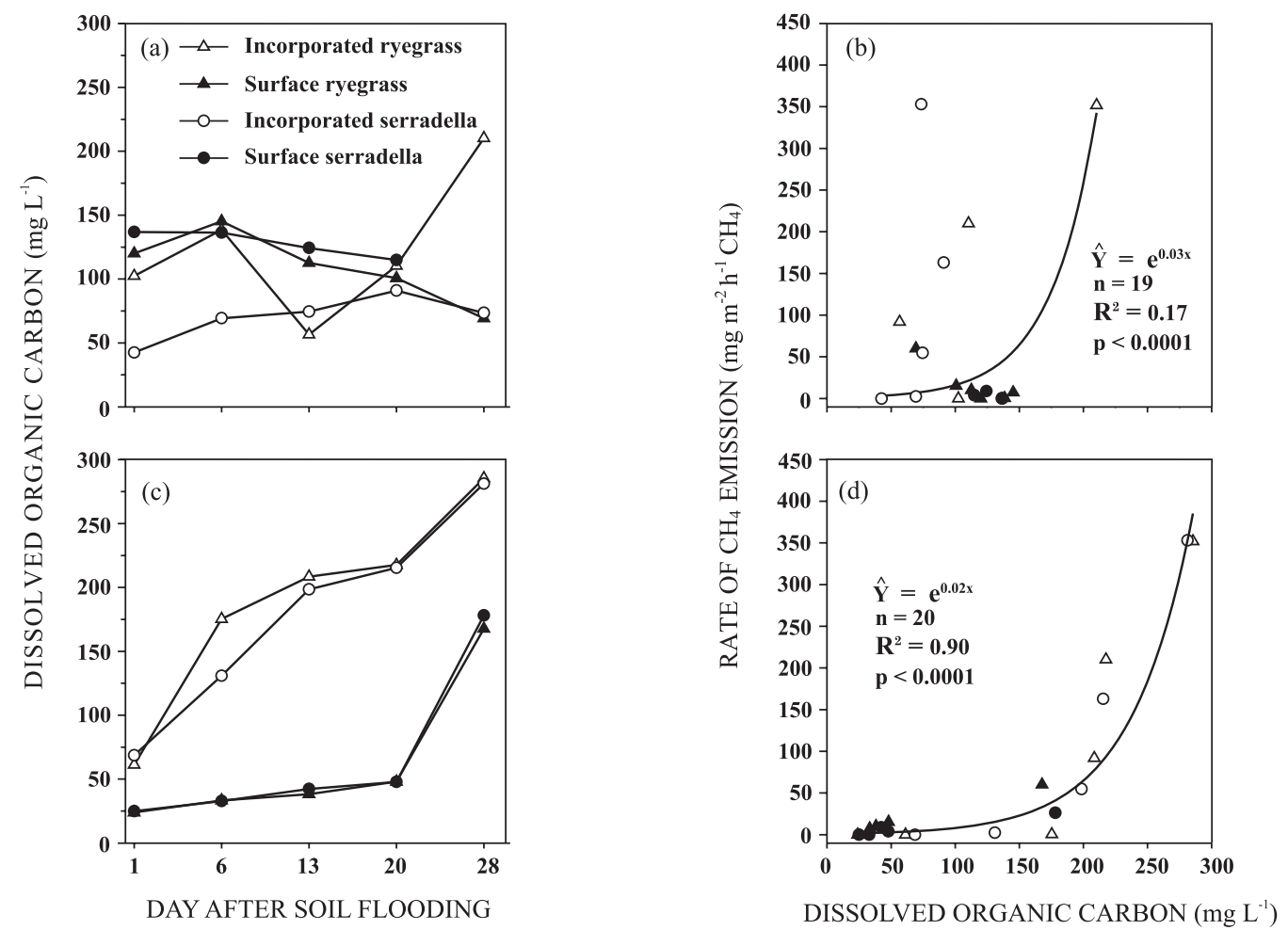

Figure 4. Concentration of dissolved organic carbon at depths of 2 and $20 \mathrm{~cm}$ (a and c, respectively) in a flooded Albaqualf under residue managements (incorporated or left on the soil surface) of ryegrass and serradella, and its relationship with $\mathrm{CH}_{4}$ emission rates (b and d, respectively). 
hand, the greater effect of air temperature on the $\mathrm{CH}_{4}$ emissions from soil with crop residue on the surface $\left(\mathrm{Q}_{10}=35\right)$ than from incorporated residue $\left(\mathrm{Q}_{10}=10\right)$ is likely due to the greater influence of air temperature on the surface $(2 \mathrm{~cm})$ than the subsurface soil layer $(20 \mathrm{~cm})$. However, it is important to note that, at the same air temperature, the soil with incorporated residues emitted more $\mathrm{CH}_{4}$ than soil with residues on the surface.

Because of the close relation between $\mathrm{CH}_{4}$ emission and temperature, the magnitude of emissions verified in this study are probably consistently larger than those under field conditions, as the temperature in the pot experiment was markedly higher due to the warming of the greenhouse by the accumulation of solar energy and due the exposure of the pot walls. For these reasons, studies carried out in the field normally indicate maximum $\mathrm{CH}_{4}$ emission rates of about $80 \mathrm{mg} \mathrm{m}^{-2} \mathrm{~h}^{-1}$ (Le Mer \& Roger, 2001; Costa, 2005), while in this study the emission rates peaked near $350 \mathrm{mg} \mathrm{m}^{-2} \mathrm{~h}^{-1} \mathrm{CH}_{4}$, i.e., about four times the fluxes usually observed under field conditions.

\section{Soil $\mathrm{N}_{2} \mathrm{O}$ emission}

In the soils with residues on the surface, the $\mathrm{N}_{2} \mathrm{O}$ emission rates did not exceed $500 \mu \mathrm{g} \mathrm{m}^{-2} \mathrm{~h}^{-1}$ in the entire experimental period (Figure 6a). From the residue-incorporated soils, in turn, $\mathrm{N}_{2} \mathrm{O}$ emissions were low until $6 \mathrm{DAF}$, but emission peaks of up to $5,180 \mu \mathrm{g} \mathrm{m}^{-2} \mathrm{~h}^{-1} \mathrm{~N}_{2} \mathrm{O}$ were observed 13 and $20 \mathrm{DAF}$. Afterwards, the emission rates decreased to values similar to those of soils with surface residue. Presumably, most of the $\mathrm{N}_{2} \mathrm{O}$ emissions until $6 \mathrm{DAF}$ was originated by denitrification of $\mathrm{NO}_{3}{ }^{-}$to $\mathrm{N}_{2} \mathrm{O}$, as suggested by the marked drop in $\mathrm{NO}_{3}{ }^{-}$contents at $20 \mathrm{~cm}$ soil depth (Figure 3d). Nevertheless, from $6 \mathrm{DAF}$ on, the soil had negligible $\mathrm{NO}_{3}$ contents at 2 and $20 \mathrm{~cm}$ depths and therefore, the $\mathrm{N}_{2} \mathrm{O}$ emitted in the subsequent period was most likely not originated from denitrification.

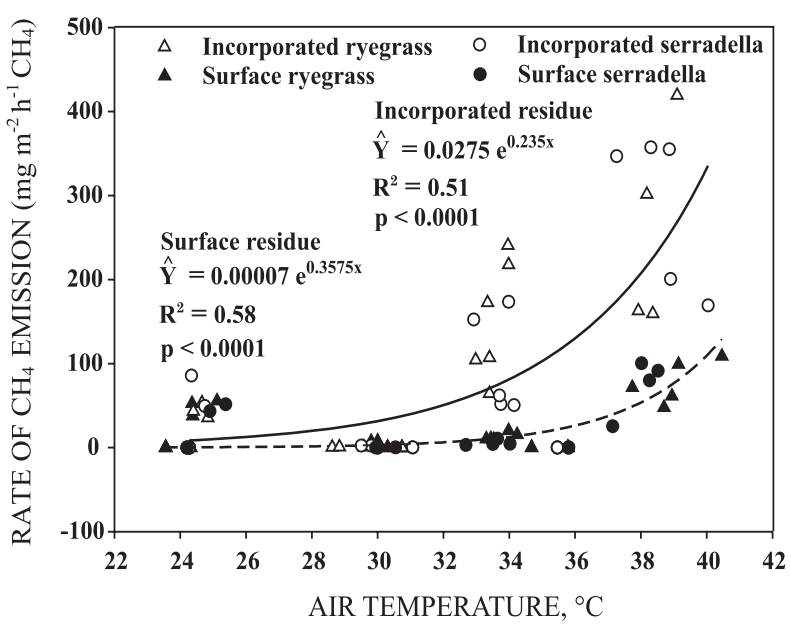

Figure 5. Relationship between $\mathrm{CH}_{4}$ soil emission rates and air temperature within the chamber.
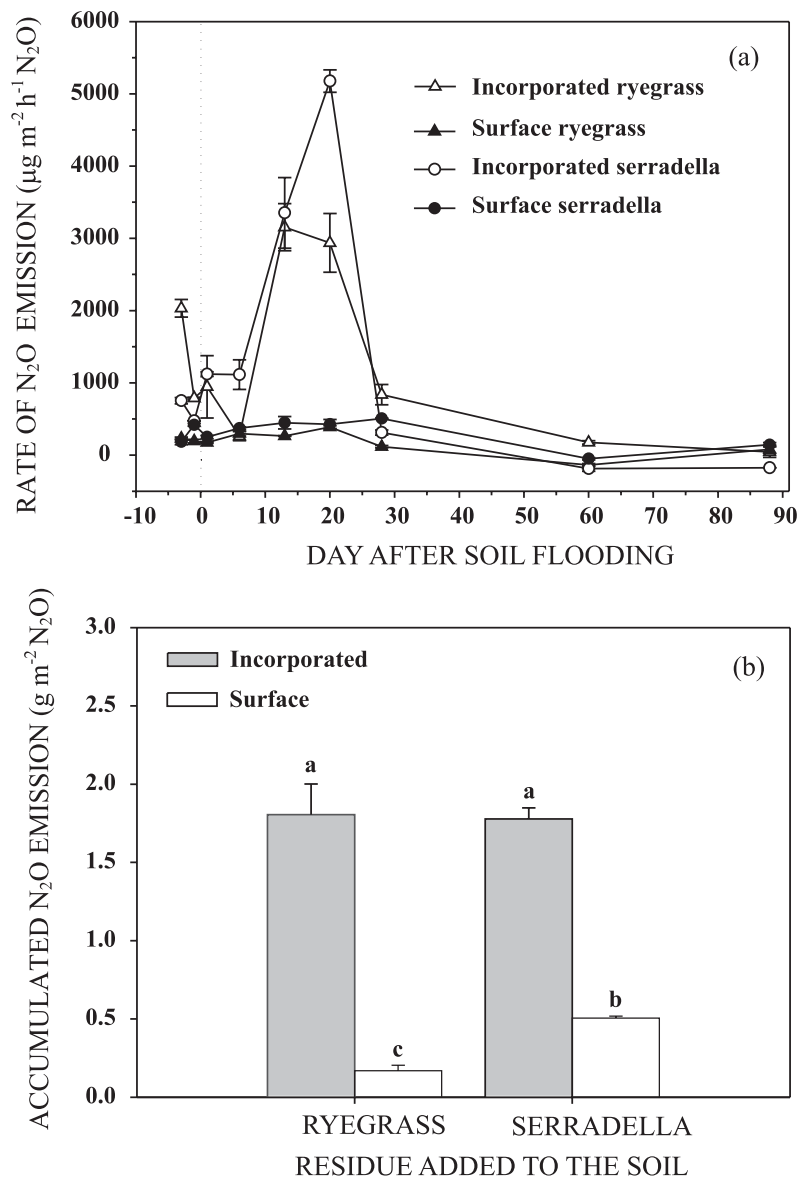

Figure 6. Emission rates (a) and accumulated emission (b) of $\mathrm{N}_{2} \mathrm{O}$ from a flooded Albaqualf cultivated with rice as affected by residue management (incorporated or left on the soil surface) of ryegrass and serradella. Vertical bars indicate standard deviation. Different letters on bars indicate statistical difference by Tukey's test at $5 \%$.

The accumulated $\mathrm{N}_{2} \mathrm{O}$ emission from the soil was 3-10 times greater in treatments with incorporated residues of ryegrass $\left(1.80 \mathrm{~g} \mathrm{~m}^{-2} \mathrm{~N}_{2} \mathrm{O}\right)$ and serradella $\left(1.78 \mathrm{~g} \mathrm{~m}^{-2} \mathrm{~N}_{2} \mathrm{O}\right)$ into the soil than when the residues were left on the soil surface. Emissions from soil with serradella residues on the surface were greater than from soil with ryegrass residues $\left(0.51\right.$ and $0.17 \mathrm{~g} \mathrm{~m}^{-2}$ $\mathrm{N}_{2} \mathrm{O}$, respectively; Figure 6b). Residue incorporation into the soil probably contributed to decrease the differences in crop residue quality, mainly if the 25 days interval between the residue application to the soil and the beginning of the experiment (rice transplanting) are taken into account. When residues were left on the surface, however, the greater emissions from serradella-amended soils were presumably due to the faster decomposition and $\mathrm{N}$ mineralization of this residue with lower $\mathrm{C} / \mathrm{N}$ ratio (18) than of ryegrass-residues (ryegrass $\mathrm{C} / \mathrm{N}$ ratio $=40$ ) (Toma \& Hatano, 2007). 
Higher $\mathrm{NH}_{4}{ }^{+}$contents with greater variations were observed at the $2 \mathrm{~cm}$ soil depth than at $20 \mathrm{~cm}$ (Figure $7 \mathrm{a}$ and $7 \mathrm{c}$ ). However, a positive and close relation between $\mathrm{N}_{2} \mathrm{O}$ emission and $\mathrm{NH}_{4}{ }^{+}$contents was only observed at $20 \mathrm{~cm}$ (Figure $7 \mathrm{~d} ; \mathrm{R}^{2}=0.61$; $\mathrm{p}<0.0001$ ), suggesting that $\mathrm{N}_{2} \mathrm{O}$ was originated by the soil nitrification process. As the low $\mathrm{O}_{2}$ availability in this soil layer would limit the occurrence of the process, the most plausible hypothesis is that the small soil volume in the pots resulted in a larger concentration of roots. This great root density may have led to high $\mathrm{O}_{2}$ diffusion through the aerenchyma, facilitating nitrification in the rhizosphere zone, with the generation of $\mathrm{N}_{2} \mathrm{O}$ from the reduction of intermediary compounds ( $\mathrm{HNO}$ and $\left.\mathrm{NO}_{2}^{-}\right)$between $\mathrm{NH}_{4}{ }^{+}$and $\mathrm{NO}_{3}{ }^{-}$(Khalil et al., 2004) and also due to the subsequent denitrification of $\mathrm{NO}_{3}{ }^{-}$produced (Arth et al., 1998).

\section{Partial global warming potential}

The estimation of $\mathrm{CH}_{4}$ and $\mathrm{N}_{2} \mathrm{O}$ emissions in amounts of equivalent $\mathrm{CO}_{2}$ serves to compare the impact of the treatments regarding the emissions of these two GHG in a combined form, taking into account the warming potential of each gas in comparison to $\mathrm{CO}_{2}$ (25 times greater for $\mathrm{CH}_{4}$ and 298 for $\mathrm{N}_{2} \mathrm{O}$ ), as well as to verify the relative contribution of $\mathrm{CH}_{4}$ and $\mathrm{N}_{2} \mathrm{O}$ to the global warming potential (GWP).
The $\mathrm{CH}_{4}$ emissions from these flooded rice fields, played a predominant role in the composition of the partial Global Warming Potential (partialGWP), contributing with 94-98.4\% of the $\mathrm{CH}_{4}+\mathrm{N}_{2} \mathrm{O}$ emissions, in equivalent $\mathrm{CO}_{2}$ amounts (Figure 8). Evaluating the influence of soil tillage systems on $\mathrm{CH}_{4}$ and $\mathrm{N}_{2} \mathrm{O}$ emissions during rice cultivation in Japan, Harada et al. (2007) also reported proportionally larger $\mathrm{CH}_{4}$ emissions, where $\mathrm{N}_{2} \mathrm{O}$ emissions (in equivalent $\mathrm{CO}_{2}$ ) reached a maximum relative participation of $3 \%$ of the emissions.

Concerning the effect of management and composition of crop residue on the $\mathrm{CH}_{4}$ and $\mathrm{N}_{2} \mathrm{O}$ emissions (partialGWP), the results indicated that residues left on the soil surface can potentially mitigate emissions from flooded soil by up to $60 \%$ compared to emissions from soil with incorporated residue (Figure 8). Similar but lower results were reported by Harada et al. (2007). Analogously to the soil tillage systems, it can be inferred that conservation tillage systems characterized by the maintenance of plant residues on the soil surface can significantly minimize GHG emissions from flooded rice fields in RS. Currently, the systems of conventional tillage and minimum tillage are still used in about $80 \%$ of the total area cultivated with rice in the state (IRGA, 2010).

It is noteworthy that, as previously discussed, the retention of solar radiation within the greenhouse, in
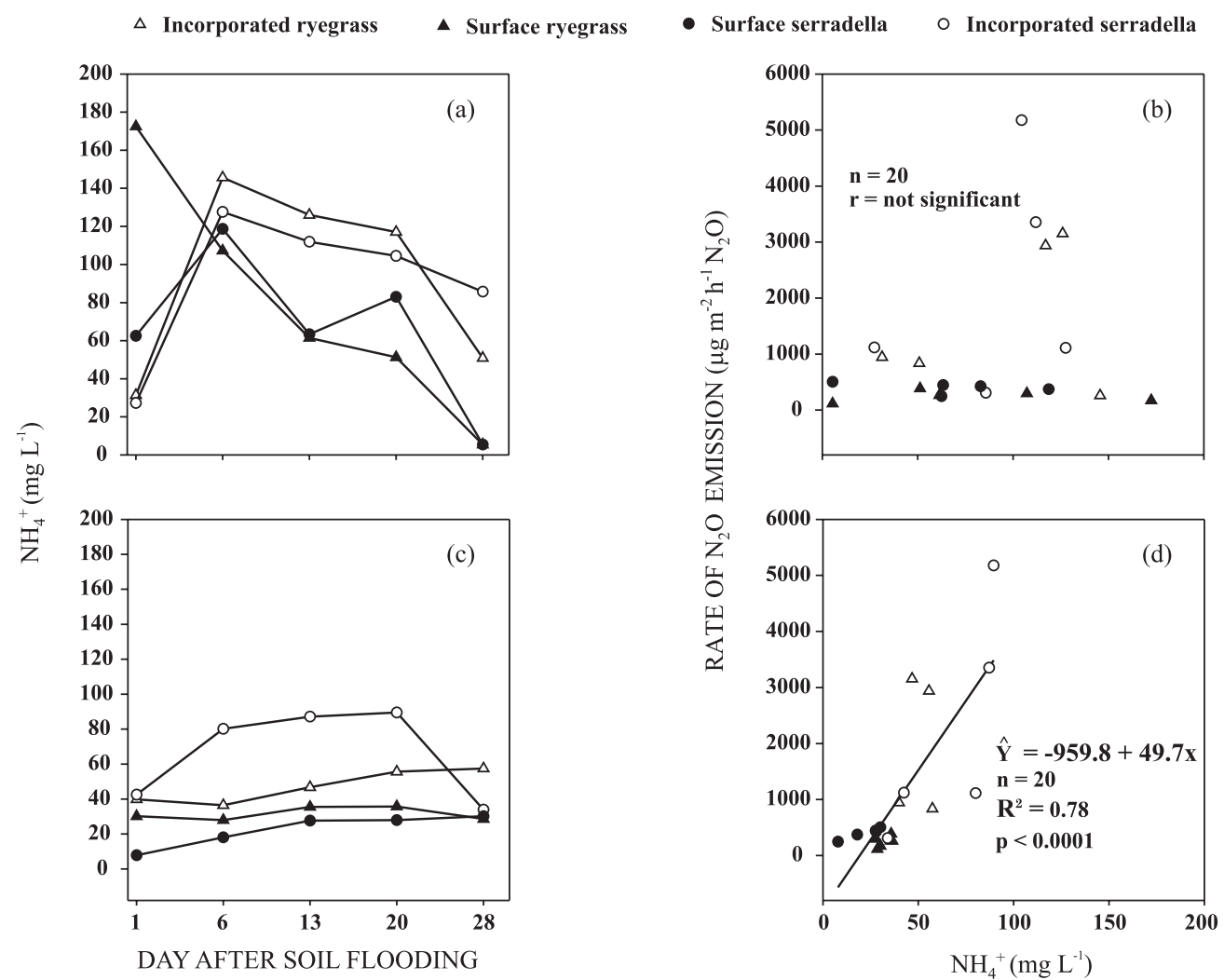

Figure 7. Concentration of ammonium $\left(\mathrm{NH}_{4}^{+}\right)$at depths of 2 and $20 \mathrm{~cm}$ (a and c, respectively) of a flooded Albaqualf as affected by residue managements (incorporated or left on the soil surface) of ryegrass and serradella, and the respective relationships with $\mathrm{N}_{2} \mathrm{O}$ soil emissions (b and d, respectively). 


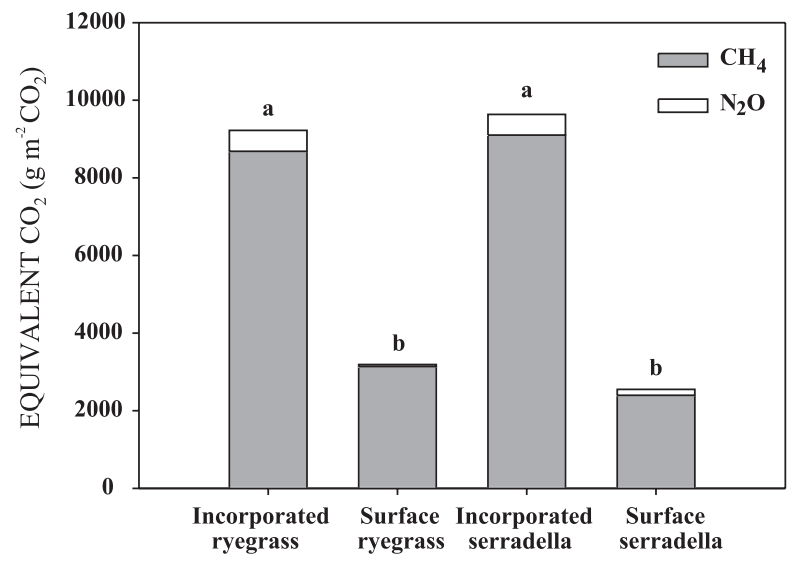

Figure 8. Accumulated $\mathrm{CH}_{4}$ and $\mathrm{N}_{2} \mathrm{O}$ emissions, expressed in equivalent $\mathrm{CO}_{2}$, from a flooded Albaqualf with rice under residue managements (incorporated or left on the soil surface) of ryegrass and serradella. Different letters on bars indicate statistical difference by Tukey's test at $5 \%$.

infrared wave form, resulted in higher experimental temperatures, leading in turn to higher $\mathrm{CH}_{4}$ emissions than under field conditions, which does not allow an individual interpretation of the gas emissions and absolute GWP values related to the impact of flooded rice cultivation on the GHG emissions.

\section{CONCLUSIONS}

1. The maintenance of cover crop residues on the soil surface mitigates methane $\left(\mathrm{CH}_{4}\right)$ and nitrous oxide $\left(\mathrm{N}_{2} \mathrm{O}\right)$ emissions from soils cultivated with rice in a flood-irrigation system.

2. The type of crop residue (grass or legume crop residue) does not affect $\mathrm{CH}_{4}$ emissions from the soil. For $\mathrm{N}_{2} \mathrm{O}$ emissions, differences among residue types occur only when left on the soil surface and, under this condition, emissions were greater from soil with legume than with grass residues.

3. The incorporation of crop residues into the soil intensifies soil reduction at $20 \mathrm{~cm}$ depth, anticipating the $\mathrm{CH}_{4}$ emissions in comparison to residues left on the soil surface. For this reason, in addition to the supply of labile $\mathrm{C}$, the subsurface soil layer is possibly the main $\mathrm{CH}_{4}$ source when crop residues are incorporated into the flooded rice soils.

4. In flooded rice systems, $\mathrm{CH}_{4}$ emissions are predominant over $\mathrm{N}_{2} \mathrm{O}$ emissions, accounting for more than $90 \%$ of the composition of the partial Global Warming Potential.

\section{ACKNOWLEDGEMENTS}

The authors appreciate the financial support provided by Fundação de Apoio a Pesquisa do Estado do Rio Grande do Sul (FAPERGS, Pronex Proc. 10/ 0054-7) and Conselho Nacional de Desenvolvimento Científico e Tecnológico (CNPq, Edital Universal Proc. 478000/2009-0). They are also grateful do CNPq for scholarships to J.A. Zanatta, C. Bayer, F.C.B. Vieira and I. Anghinoni, and to CAPES for a fellowship to T. Zschornack.

\section{LITERATURE CITED}

ALI, M.A.; LEE, C.H.; KIM, S.Y. \& KIM, P.J. Effect of industrial by-products containing electron acceptors on mitigating methane emission during rice cultivation. Waster Manag., 29:2759-2764, 2009.

ARTH, I.; FRENZEL, P. \& CONRAD, R. Denitrification coupled to nitrification in the rhizosphere of rice. Soil Biol. Biochem., 30:509-515, 1998.

AULAKH, M.S.; KHERA, T.S.; DORAN, J.W. \& BRONSON, K.F. Denitrification, $\mathrm{N}_{2} \mathrm{O}$ and $\mathrm{CO}_{2}$ fluxes in rice-wheat cropping system as affected by crop residues, fertilizer $\mathrm{N}$ and legume green manure. Biol. Fert. Soils, 34:375-389, 2001.

BRASIL. Ministério da Ciência e Tecnologia. Primeiro Inventário Brasileiro de Emissões Antrópicas de Gases de Efeito Estufa - Relatórios de Referência. Disponível em: <http://www.mct.gov.br/index.php/content/view/ 17341.html.> Acesso em: 23 mar. de 2008.

CERRI, C.C.; MAIA, S.M.F.; GALDOS, M.V.; CERRI, C.E.P.; FEIGL, B.J. \& BERNOUX, M. Brazilian greenhouse gas emissions: The importance of agriculture and livestock. Sci. Agric., 66:831-843, 2009.

COCHRAN, V.L.; SPARROW, E.B.; SCHLENTNER, S.F. \& KNIGHT, C.W. Long-term tillage and crop residue management in the subartic: Fluxes of methane and nitrous oxide. Can. J. Soil Sci., 77:565-570, 1997.

COMPANHIA NACIONAL DE ABASTECIMENTO - CONAB. $6^{\circ}$ Levantamento de safras 2009/2010. Disponível em: $<$ http://www.conab.gov.br/conabweb/download/safra/ 6graos_09.03.10.pdf>. Acesso em: 24 Mar. de 2010.

CONRAD, R. Control of microbial methane production in wetland rice fields. Nutr. Cycl. Agroecosyst., 64:59-69, 2002.

COSTA, F.S. Estoques de carbono orgânico e efluxos de dióxido de carbono e metano de solos em preparo convencional e plantio direto no subtrópico brasileiro. Porto Alegre, Universidade Federal do Rio Grande do Sul, 2005. 129p. (Tese de Doutorado)

DALAL, R.C.; ALLEN, D.E.; LIVESLEY, S.J. \& RICHARDS, G. Magnitude and biophysical regulators of methane emission and consumption in the Australian agricultural, forest, and submerged landscape: A review. Plant Soil, 309:43-76, 2008.

EMPRESA BRASILEIRA DE PESQUISA AGROPECUÁRIA EMBRAPA. Centro Nacional de Pesquisa Agropecuária Solos. Sistema brasileiro de classificação de solos. 2.ed. Rio de Janeiro, 2006. 306p. 
FORSTER, P.; RAMASWAMY, V.; ARTAXO, P.; BERNTSEN, T.; BETTS, R.; FAHEY, D.W.; HAYWOOD, J.; LEAN, J.; LOWE, D.C.; MYHRE, G.; NGANGA, J.; PRINN, R.; RAGA, G.; SCHULZ, M. \& van DORLAND, R. Changes in atmospheric constituents and in radiative forcing. In: SOLOMON, D.; QIN, D.; MANNING, M.; CHEN, Z.; MARQUIS, M.; AVERYT, K.B.; TIGNOR, M. \& MILLER H. L. Climate change 2007: The physical science basis. Contribution of working group I to the fourth assessment report of the intergovernmental panel on climate change. Cambridge, Cambridge University Press, 2007. p.129-234.

FRAGA, T.I.; CARMONA, F.C.; ANGHINONI, I.; GENRO JUNIOR, S.A. \& MARCOLIN, E. Flooded rice yield as affected by levels of water salinity in different stages of its cycle. R. Bras. Ci. Solo., 34:175-182, 2010.

GOMES, J.; BAYER, C.; COSTA, F.S.; PICCOLO, M.C.; ZANATTA, J.A.; VIEIRA, F.C.B. \& SIX, J. Soil nitrous oxide emissions in long-term cover crops-based rotations under subtropical climate. Soil Tillage Res., 106:36-44, 2009.

HARADA, H.; KOBAYASHI, H. \& SHINDO, H. Reduction in greenhouse gas emissions by no-tilling rice cultivation in Hachirogata polder, northern Japan: Life-cycle inventory analysis. Soil Sci. Plant Nutr., 53:668-677, 2007.

HOSONO, T. \& NOUCHI, I. The dependence of methane transport in rice plants on the root zone. Plant Soil, 191:233-240, 1997.

HUANG, B.; YU, K. \& GAMBRELL, R.P. Effects of ferric iron reduction and regeneration on nitrous oxide and methane emissions in a rice soil. Chemosphere, 74:481-486, 2009.

INSTITUTO RIO GRANDENSE DO ARROZ - IRGA. Censo da lavoura orizícola 2005. Disponível em: <http:// www.irga.rs.gov.br/arquivos/20060524160029.pdf> Acesso em: 19 nov. de 2009.

JOHNSON-BEEBOUT, S.E.; ANGELES, O.R.; ALBERTO, M.C.R. \& BURESH, R.J. Simultaneous minimization of nitrous oxide and methane emission from rice paddy soils is improbable due to redox potential changes with depth in a greenhouse experiment without plants. Geoderma, 149:45-53, 2009.

KAEWPRADIT, W.; TOOMSAN, B.; VITYAKON, P.; LIMPINUNTANA, V.; SAENJAN, P.; JOGLOY, S.; PATANOTHAI, A. \& CADISCH, G. Regulating mineral $\mathrm{N}$ release and greenhouse gas emissions by mixing groundnut residues and rice straw under field conditions. Eur. J. Soil Sci., 59:640-652, 2008.

KHALIL, K.; MARY, B. \& RENAULT, P. Nitrous oxide production by nitrification and denitrification in soil aggregates as affected by $\mathrm{O}_{2}$ concentration. Soil Biol. Biochem., 36:687-699, 2004.

LE MER, J. \& ROGER, P. Production, oxidation, emission and consumption of methane by soils: A review. Eur. J. Soil Biol., 37:25-50, 2001.

LU, Y.; WASSMANN, R.; NEUE, H.U. \& HUANG, C. Dynamics of dissolved organic carbon and methane emissions in a flooded rice soil. Soil Sci. Soc. Am. J., 64:2011-2017, 2000.
MACEDO, V.R.M.; MARCHEZAN, E.; SILVA, P.R.F.; ANGHINONI, I. \& ÁVILA, L.A. Manejo da água e da adubação para maior sustentabilidade da lavoura de arroz pré-germinado no RS. Cachoeirinha, Instituto Rio Grandense do Arroz, 2007. 20p. (Boletim Técnico, 3)

MARCHESAN, E.; ZANELLA, R.; AVILA, L.A.; CAMARGO, E.R.; MACHADO, S.L.O. \& MACEDO, V.R.M. Rice herbicide monitoring in two Brazilian rivers during the rice growing season. Sci. Agric., 64:131-137, 2007.

MARCHEZAN, E.; GARCIA, G.A.; CAMARGO, E.R.; MASSONI, P.F.S.; AROSEMENA, D.R. \& OLIVEIRA, A.P.B.B. Manejo da irrigação em cultivares de arroz no sistema pré-germinado. Ci. Rural, 37:45-50, 2007.

MINAMIKAWA, K.; \& SAKAI, N. The effect of water management based on soil redox potential on methane emission from two kinds of paddy soils in Japan. Agric. Ecosyst. Environ., 107:397-407, 2005.

MINAMIKAWA, K. \& SAKAI, N. The practical use of water management based on soil redox potential for decreasing methane emission from a paddy field in Japan. Agric. Ecosyst. Environ., 116:181-188, 2006.

RATH, A.K.; RAMAKRISHNAN, B. \& SETHUNATHAN, N. Temperature dependence of methane production in tropical rice soils. Geomicrobiol. J., 19:581-592, 2002.

REIS, J.C.L. \& SAIBRO, J.C. Integração do arroz com pastagens cultivadas e pecuária. In: GOMES, A.S. \& MAGALHÃES Jr., A.M. Arroz irrigado no sul do Brasil. Brasília, Embrapa Informação Tecnológica, 2004. p.831860.

SCHÜTZ, H.; SEILER, W. \& CONRAD, R. Influence of soil temperature on methane emission of methane from rice paddy. Biogeochemistry, 11:77-85, 1990.

SCIVITTARO, W.B.; SILVA, C.A.S.; ANDRES, A.; REIS, J.C.L.; MATTOS, M.L.T.; TRIVELIN, P.C.O. \& MURAOKA, T. Potencial de utilização de leguminosas de inverno como fonte alternativa de nitrogênio para a cultura do arroz irrigado. Pelotas, Embrapa Clima Temperado, 2002. 5p. (Comunicado Técnico, 81)

SEGERS, R. Methane production and methane consumption: A review of processes underlying wetland methane fluxes. Biogeochemistry, 41:23-51, 1998.

SETYANTO, P.; ROSENANI, A.B.; MAKARIM, A.K.; FAUZIAH, C.I.; BIDIN, A. \& SUHARSIH. Soil controlling factors of methane gas production from flooded rice fields in Pati District, Central Java. Indonesia J. Agric. Sci., 3:20-31, 2002 .

SHAN, Y.; CAI, Z.; HAN, Y.; JOHNSON, S.E. \& BURESH, R.J. Organic acid accumulation under flooded soil conditions in relation to the incorporation of wheat and rice straws with different C:N ratios. Soil Sci. Plant Nutr., 54:46-56, 2008.

SILVA, D.R.O.; AVILA, L.A.; AGOSTINETTO, D.; DAL MAGRO, T.; OLIVEIRA, E.; ZANELLA, R. \& NOLDIN, J.A. Monitoramento de agrotóxicos em águas superficiais de regiões orizícolas no sul do Brasil. Ci. Rural, 39:23832389, 2009 . 
STEPNIEWSKI, W. \& STEPNIEWSKA, Z. Selected oxygendependent process - Response to soil management and tillage. Soil Tillage Res., 102:193-200, 2009.

TEDESCO, M.J.; GIANELLO, C.; BISSANI, C.A.; BOHNEN, H. \& VOLKWEISS, S.J. Análise de solo, plantas e outros materiais. 2.ed. Porto Alegre, Universidade Federal do Rio Grande do Sul, 1995. 174p. (Boletim Técnico, 5)

TOMA, Y. \& HATANO, R. Effect of crop residue C:N ratio on $\mathrm{N}_{2} \mathrm{O}$ emissions from gray lowland soil in Mikasa, Hokkaido, Japan. Soil Sci. Plant Nutr., 53:198-205, 2007.

van HULZEN, J.B.; SEGERS, R.; van BODEGOM, P.M. \& LEFFELAAR, P.A. Temperature effects on soil methane production: An explanation for observed variability. Soil Biol. Biochem., 31:1919-1929, 1999.
WANG, B.; XU, Y.; WANG, Z.; LI, Z.; DING, Y. \& GUO, Y. Methane production potentials of twenty-eight rice soils in China. Biol. Fert. Soils, 29:74-80, 1999.

XIONG, Z. Q.J.; XING, G. X. \& ZHU, Z.L. Nitrous oxide and methane emissions as affected by water, soil and nitrogen. Pedosphere, 17:146-155, 2007.

YANG, S.-S. \& CHANG, H.-L. Effect of environmental conditions on methane production and emission from paddy soil. Agric. Ecosyst. Environ., 69:69-80, 1998. 